\title{
HENRY THOREAU AND \\ SASKATCHEWAN'S \\ NATURAL HISTORY
}

by VICTOR C. FRIESEN*

When Louis Agassiz, the zoology nd geology professor at Harvard University a century ago, was once sked what he had done on his lolidays, he reportedly answered that e had got halfway across his backyard - there was so much to observe. His eelings were akin to those of his icquaintance, Henry Thoreau, who ometimes sent the professor iological specimens from Concord, Massachusetts. It was Thoreau's boast hat he had travelled much in his hative township of Concord, implying hat it was not necessary to travel lsewhere - a significant world was at his very feet.

Yet readers of Thoreau's nature classic, Walden (1854), may be inerested to know that Thoreau had a keen interest in "Saskatchewan and idjacent regions". True, the nearest he ever got to the Canadian Northwest was a journey to Minnesota in 1861 with a fellow botanist, Horace Mann, $\mathrm{Jr}$. It was there that they gained some first-hand knowledge of prairie plants, and it was there too that Thoreau first saw, and became fascinated by, the Thirteen-lined and the Franklin Ground squirrels, two of the common "gophers" of our own area farther north.

Thoreau's interest in Saskatchewan natural history stemmed chiefly from his reading of travel books. One of his

*P.O. Box 65,

Rosthern, Saskatchewan

SOK 3 RO favorites was Travels and adventures in Canada and the Indian Territories between the years 1760 and 1776, written by Alexander Henry (the Elder). Henry, a fur trader, states in the preface that his account will describe, among other things, "the geography and natural history" of the region." Henry's "region", included Cumberland House on the Saskatchewan River, Beaver (now Amisk) Lake, the Churchill River system to the north and the plains area to the south. In his own travel book, $A$ week on the Concord and Merrimack rivers (1849) Thoreau comments on the country traversed by Henry in these terms: it is "an immense and shaggy but sincere country, summer and winter, adorned with chains of lakes and rivers ...",

Thoreau praises Henry's Travels for giving "not the annals of the country, but the natural facts, or perennials, which are ever without date." One such "perennial" pertains to the lighter yellowish-green colour of new shoots on pine branches. These shoots tend to bend eastward, Henry says, and serve Canadian Indians as a direction finder. Thoreau notes the same phenomenon in his own Concord woods a hundred years later. ${ }^{12}$

Of particular interest to Thoreau was Henry's description of a rocky hill near Beaver Lake. ${ }^{3}$ This account so influenced Thoreau that he borrowed some of the fur trader's phrases to describe his own climb of Mount Katahdin, Maine's highest mountain. Thoreau's celebrated description of 


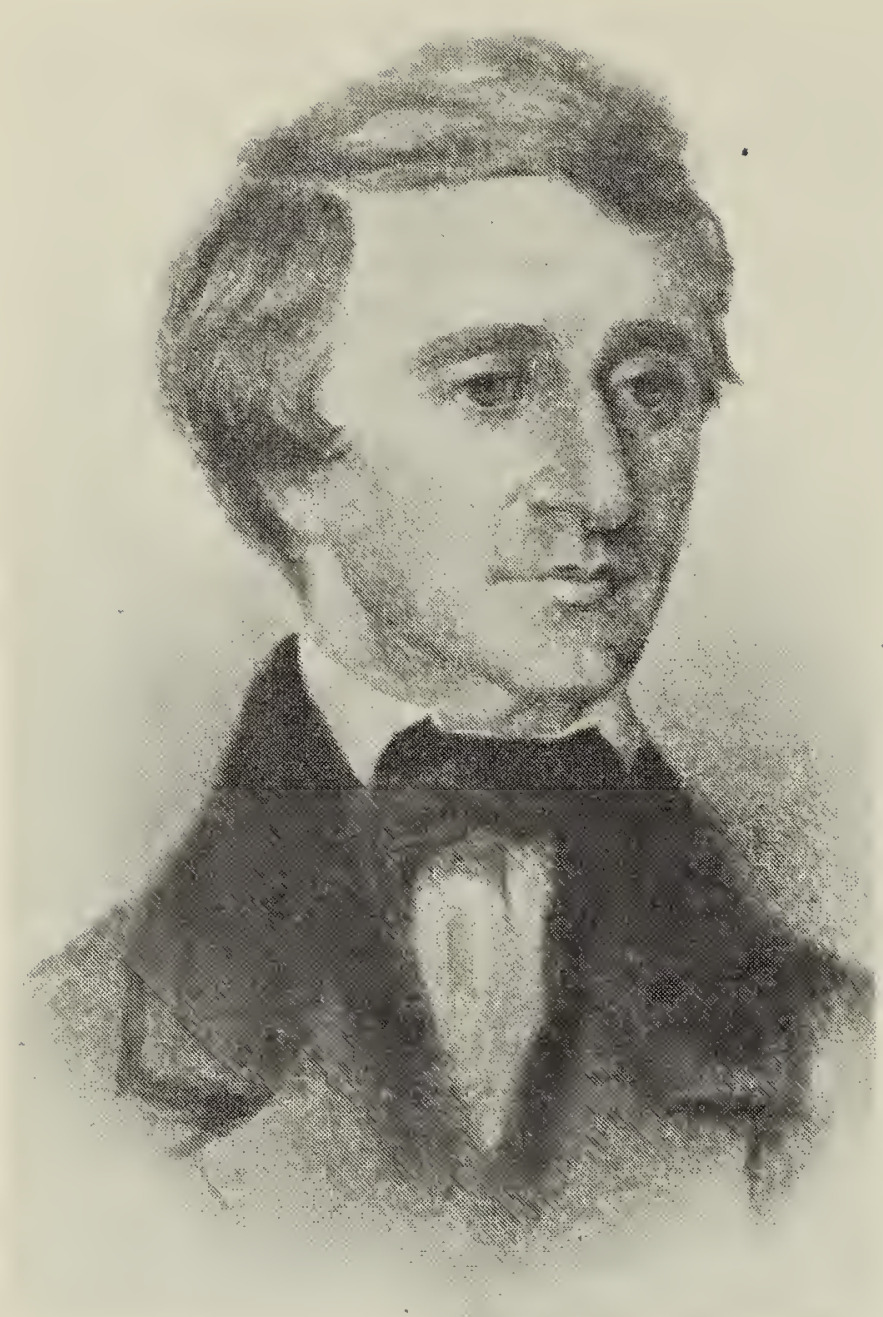

Thoreau Society Inc.

Henry David Thoreau

this incident is recorded in the first chapter of The Maine Woods (1864). Wishing to convey an impression of the mountain's awesome grandeur, Thoreau refers to Katahdin as the natural home of legendary Titans, ${ }^{10}$ just as Henry had so referred to the almost inaccessible hill in Saskatchewan.

Thoreau's interest in the Saskatchewan region is also apparent in his reading of Henry Youle Hind's Northwest Territory: Reports of progress, together with a preliminary and general report on the Assiniboine and Saskatchewan Exploration Expedition. Since this Canadian government publication was printed in Toronto, it would have been an obscure book in Massachusetts. Yet Thoreau was commenting on this edition in his Journal the following year.

In Hind's account Thoreau found much factual reporting of a scientific nature. Facts like these always were grist to Thoreau's mill. He would have enjoyed learning, for instance, that Grizzly Bears still roamed the treeless plains, for Hind took precautions tha his party should not be taken unaware at night by such marauders. ${ }^{4}$ Hind tell too of Whooping Cranes in the Touch wood Hills, where he says they are "common." When he refers to the fact that only small aspens and willows grow on the plains because Indian tribes periodically set fire to the prairies, ${ }^{6}$ Thoreau comments that the seeds of these trees, being both abundant and easily distributed by the wind, are the most likely to start growing afresh in burned-over areas.

Thoreau's interest in books on Arctic exploration further acquainted him with the Saskatchewan scene. For example, Sir John Franklin's Narrative of a Journey to the Shores of the Polar Sea (1819-1822) describes in part an overland journey from Hudson Bay which takes Franklin up the Saskatchewan River to Fort Carlton, before proceeding north to the Arctic Ocean. Sir John Richardson accompanied Franklin as surgeon and naturalist and he remained behind for some months at Cumberland House and at Carlton while collecting biological specimens.

Richardson's account of this exercise, as given in Chapter III of the Narrative, reads very much like portions of Thoreau's own Journal which describes Concord flora and fauna. Both men have a sensuous approach to natural phenomena, recording many details about such things as colouration and taste, and both are interested in local folklore. This passage, by Richardson, is characteristic of both authors:

... a berry of bluish white colour ... is named musqua-meena, bearberry, because these animals are said to fatten on it. The dwarf Canadian cornel bears a corymb of red berries, which are highly 
